\title{
Poeiras: experiências literárias e invenções de história ${ }^{1}$
}

\author{
Poeiras: literary experiences and invention of history
}

\author{
Eudes Fernando Leite ${ }^{2}$ \\ Frederico Augusto Garcia Fernandes ${ }^{3}$
}

\section{RESUMO}

Este texto analisa o conto Nessa poeira não vem mais seu pai, do escritor Augusto César Proença. Sob o enfoque das teorias da história e da literatura, procura-se compreender e demonstrar os mecanismos de produção do conto e sua posterior migração para o cinema, passando por questões ligadas à oralidade e à memória e destacando a presença da experiência histórica que ocupa o lugar de fornecedora de conteúdo para a estrutura da narrativa ficcional verificada em Nessa poeira...

Palavras-chave: História. Literatura. Pantanal. Augusto Proença. Cinema.

\section{ABSTRACT}

In this article we have analysed the short history Nessa poeira não vem mais seu pai, by Augusto César Proença. Take into account theories of history and literature, we tried to understand and demonstrate the mechanisms of production of this short history as well as its adaptation to cinema, dealing with issues such as orality and memory, and focusing on the historical experience, which is the standpoint of structure of fictional narrative in Nessa poeira...

Keyword: History. Literature. Pantanal. Augusto Proença. Cinema.

1 Versão inicial deste texto foi apresentada no X Encontro Nacional de História Oral; Testemunhos: história e política, realizado na Universidade Federal de Pernambuco (UFPE), no primeiro semestre de 2010.

2 Eudes Fernando Leite. Doutor em História pela Unesp/Assis, professor associado III na Universidade Federal da Grande Dourados (UFGD). Atua na Graduação e na Pós-Graduação em História (Mestrado e Doutorado) nessa instituição.

3 Frederico Fernandes, pesquisador produtividade CNPq (nível 2), é professor associado do Departamento de Letras Vernáculas e Clássicas da UEL e coordenador da área de Letras, Linguística e Artes junto à Fundação Araucária. Pesquisa no Pantanal desde 1992, tendo publicado vários livros e artigos sobre a poesia oral e literatura daquela região. 
São homens, filho, e os homens foram feitos pra morrer. (Augusto Proença; Raízes do Pantanal)

Este é o princípio da história que será aqui narrada e discutida: em 1994, a Rádio France Internacionale divulgava o resultado do Concurso Guimarães Rosa, no qual mais de novecentos autores brasileiros inscreveram seus textos, contos na grande maioria. Do certame participaram ainda escritores franceses, portugueses, angolanos, moçambicanos, caboverdianos, guineeses, austríacos, holandeses, cubanos e equatorianos. Num conjunto de trinta contos finalistas, encontrava-se Nessa poeira não vem mais seu pai, escrito por Augusto Proença, autor corumbaense, cujas obras ancoram-se na complexa relação memória, história e literatura.

Nessa poeira... inscreve-se em imemorial relação de textos nos quais o fato trágico se impõe como figura de maior expressividade, malgrado o desempenho das personagens humanas ao se esforçarem para ocupar o centro da operacionalização da trama. É um conto de bastante simplicidade na medida em que é metáfora-memória do modus vivendi pantaneiro, por sua vez, integrante da ruralidade brasileira, local em que o tempo aparentemente não passa, tornando a experiência humana um fenômeno melancólico, quando não desprovido de tensões explícitas.

O desenrolar da história tem como palco uma propriedade no Pantanal brasileiro, uma fazenda na qual é difícil alcançar o fim das léguas do patrão, onde a principal atividade econômica é a bovinocultura. Nessa paisagem, quase sempre pensada como paradisíaca, ambiente em que não há espaço para o conflito, desenrola-se a história-ficção. A trama envolve, essencialmente, quatro personagens: o pai-peão, a mãe-esposa, o menino-filho, além da única personagem detentora de um nome próprio, seu Zé Bento, outro peão, portador da triste notícia da morte do pai-peão. Zé Bento, um nome rotineiro se coloca en passant como aquele que porta uma novidade ruim e talvez, por isso, tenha merecido uma identidade: sua tarefa é por demais desestabilizadora na trama, o que implica num nome, ainda que o Bento não signifique, necessariamente, uma benção.

Toda a trama ocorre em torno da cotidiana rotina do menino que, ao enxergar uma nuvem de poeira, sonorizada pelo berrante e que envolve uma boiada, se mobiliza alegremente para receber o pai que chegava de mais uma jornada de trabalho. Essa situação fornece o esteio para que o fato trágico e a rotina daquele ambiente se entrecruzassem e estabelecessem uma marca profunda na relação familiar. A morte do pai numa rodada do cavalo - nos dias de hoje, um acidente de trabalho - enuncia o fenecimento da figura central que ilumina a identidade do pequeno garoto, abrindo espaço para que a lembrança do progenitor se transforme na referência do amor rústico, da afetividade mesclada à iniciação mundo do trabalho no Pantanal. Ali não há espaço para a fragilidade. Trata-se de um mundo 
bruto em que a força é relevante e, não raras vezes, decisiva à sobrevivência humana: "Bugre taludo de forte, assim era o pai. Pegava o machado e deixava a lâmina tombar em cada gemido de peito aberto" (PROENÇA, 1996, p. 34). Era o pai-peão o modelo da personalidade para o filho, um pequeno projeto de peão a ser incorporado futuramente no cosmos local, em que a lida no campo - o mundo do trabalho - envolvia desde há muito tempo a domesticação do bovino e o enfrentamento com a natureza e, da mesma forma, a domesticação do trabalhador.

No estereótipo dessa personagem, encontra-se o peão-pantaneiro de Proença e que já fora apresentado noutro texto com pretensão historiográfica. Em 1992, Proença publicou Pantanal: gente, tradição e História, livro que perseguiu o lugar de explicação histórica, cujo foco foi a fundação de fazendas no Pantanal, especialmente na sub-região da Nhecolândia. No capítulo em que escreve sobre a formação das grandes propriedades, Proença retoma a antiga concepção da mistura das raças formadoras do povo brasileiro, negro, branco e índio, e identifica a origem do trabalhador das fazendas pantaneiras:

O vaqueiro se originou do índio: do guató, do guaná, dos xamacocos e guaicurus, os primitivos donos da terra; também do negro escravo que veio para as minas de ouro e, depois, para as plantações de cana. Acompanhou o desbravador por caminhos vários e, já no Sul, recebeu a influência do sangue paraguaio, absorvendo-lhe os costumes, os traços fisionômicos, formando um tipo diferente do vaqueiro do Norte: o típico poconeano.(PROENÇA, 1992, p. 55). ${ }^{4}$

O pai-peão do conto e depois do filme ocupa essa representação identitária: um ser rústico, mestiço e afetivamente ensimesmado, porque forjado no ambiente e nas relações hostis existentes no Pantanal. É um homem de poucas-falas, mais afeito ao trabalho pesado, ao enfrentamento com o mundo. Essa caracterização ganhou relevo e foi tomada como um modelo de referência identitária local, baseada sobretudo na capacidade do habitante pantaneiro ao enfrentar obstáculos do meio, desenvolvendo estratégias de vida no Pantanal. ${ }^{5}$ Porção desse modelo pode ser encontrada em narrativas obtidas em entrevistas com trabalhadores pantaneiros na década de 1990.

\footnotetext{
${ }^{4}$ Em Leite (2003. p. 68 e segs) encontram-se algumas observações a respeito da construção representacional sobre o trabalhador das fazendas, presente no texto de Proença. É de notar ainda que a noção do "encontro" de raças é um mecanismo de compreensão que dominou parte do pensamento brasileiro durante a primeira metade do século XX, obliterando as distinções inerentes à participação de cada "raça" nessa miscigenação. Sobre essa discussão, remetemos à Schwarcz (1995).

5 Em trabalho específico discute a construção da representação identitária do homem pantaneiro, sublinhando a figura do peão e do camarada, figuras diretamente ligadas às atividades cotidianas da fazenda de gado no Pantanal. Esses trabalhadores, por conta de suas habilidades, por conta de suas características éticas e das imagens que expressam acerca da região, informam intensamente sobre a autoidentidade, mediando-a com as leituras externas a eles atribuídas. Leite (2012, p. 33-44).
} 
O longo processo de conquista da região que oferece o palco ao conto se intensificou logo após o fim da Guerra com o Paraguai, ocasião em que as famílias Gomes da Silva e Barros se deslocaram do Norte mato-grossense na busca de recuperar terras ocupadas pelo exército Guarani. Uma das fontes históricas mais ricas para se conhecer a migração das duas famílias encontra-se no livro de José de Barros, Lembranças para meus filhos e descendentes, escrito em 1910, obra que favorece enxergar certas minudências da colonização e da estruturação das propriedades no Pantanal próximo à cidade de Corumbá.

A colonização do Pantanal levou a significação do espaço e do homem que o desenharia, recorrendo a componentes do processo de amansamento da região, ou seja, esse fenômeno associa homem e natureza enquanto oponentes e, paradoxalmente, aliados na consolidação e fixação de uma imagem para o habitante local. A representação do homem pantaneiro, entendida aqui como a consagração de uma imagem que ocupa o lugar do objeto ou do fenômeno, agrega rusticidades, bravura e, de certa forma, insinua certo grau de violência, aspecto esse negado por muitos deles (AQUINO, Valdomiro Lemos de, 1996. Entrevista). O peão pantaneiro idealizado é uma representação poderosa e impactante na medida em que realça sua habilidade no trabalho, obscurece as relações de mando que se tornam sutis na medida em que o peão, até o advento da legislação trabalhista no período Vargas - a qual impôs mudanças legais nas relações entre patrões e empregados - é referido como um modelo de bravura. (LEITE, 2003, p. 119).

O conto aqui sondado é uma metáfora-memória do modus-vivendi pantaneiro, prestando-se a fornecer representação ficcional a muitas histórias de vida que sustentam o escopo que nutre toda a trama. Trata-se de um texto que se apropriou e reproduziu circunstâncias e eventos que integram o longo processo de instalação e desenvolvimento da pecuária no Pantanal, em especial, na porção localizada no estado de Mato Grosso do Sul. As personagens são igualmente atores de um passado e, em boa medida, do presente em que o homem vivencia situações de enfrentamentos com a natureza e com os animais que pretende domesticar. Na trama encontra-se presente uma tentativa de síntese de muitas trajetórias de vida que constituem a historicidade da colonização no Pantanal, um fenômeno que ofereceu ao autor elementos vivazes para beber da história local e da memória familiar e, ato contínuo, transformá-las em literatura.

No centro da trama, o ombreamento com a brutalidade ofereceu o motivo de vida e de morte do pai: ele falecera por que o cavalo pisou em buraco de tatu, durante uma correria na perseguição a um boi arisco. No contexto dessa circunstância (mortal!), as atividades inerentes ao mundo do trabalho no Pantanal se configuram como ameaçadoras das condições de vida; contemporaneamente denominaríamos essa situação como um acidente de trabalho, mas no cotidiano de uma grande propriedade pantaneira, as atividades de manejo do gado implicam a vivência ambígua da vida e da morte, do trabalho e do lazer, do homem com a natureza. Nasce-se para viver e para morrer! Morrer no campo é uma 
possibilidade constante e, nessa situação em particular, todas as habilidades do peão não foram suficientes para livrá-lo do encontro com a morte. Mas, da perspectiva da narrativa literária, nesta morte em que o autor bafeja o sopro da vida sobre o texto, assinala-se um instante da história. Não se trata aqui do adágio "a vida imita a arte, que imita a vida", mas do amálgama disforme entre a constituição do objeto artístico e sua imbricação com a experiência, individual ou coletiva, pessoal ou alheia, favorecendo a emergência de um texto contaminado por antecedentes genéticos nem sempre identificáveis na temporalidade contemporânea à existência do autor.

O conto de Proença se apropria de eventos integrantes do cotidiano histórico regional, em particular do Pantanal sul-mato-grossense, e os encerra no plano literário, nível em que a invenção se atrela ao verossímil e fornece a estrutura e a conjuntura nas quais os eventos se desdobram e conferem sentidos à história narrada. A história incrustada em Poeira é uma história de muitos e, igualmente, de ninguém; suas partículas fazem parte de diversas circunstâncias verificadas na vida de muitas famílias que habitaram e habitam o Pantanal. A invenção, consequentemente, nunca é plena e íntegra, ela se apresenta ancorada num nicho histórico que conforma a ação criativa. Igualmente, parece impossível pensar na separação entre o plano literário e o histórico. Roland Barthes (1988, p. 127-128), por sua vez, observa que o historiador pode enfatizar em sua narrativa tanto unidades indiciais (por meio da recorrência de significados implícitos), que atraem a História para um campo de força metafórico, avizinhando-a do lírico e do simbólico; como, também, enfatizar algumas unidades funcionais (por meio da ênfase à ação), o que torna a História assemelhada à epopeia. Assim, a história amalgama criação e fato, transpirando um quê de poesia e o conto em questão não escapa à observação barthesiana.

Talvez se possa pensar, para efeitos de entendimento, na ocorrência de uma migração do conjunto de ações humanas (o plano histórico) para outro ambiente, qual seja o campo literário no qual as ações das personagens, suas características psicológicas estejam libertas das condicionantes existenciais e, paradoxalmente, submetidas aos ditames do autor. Esse demiurgo da ficção é igualmente o arranjador de estruturas sociais internas ao texto que se deslindam parcialmente da memória do criador, uma vez que em outros momentos - ou noutros escritos - é possível flagrar Proença narrando a história do Pantanal, tomando como eixo condutor das ações, a vontade dos seus antepassados geralmente significados como pioneiros.

A poeira levantada por Augusto Cesar Proença se manifesta no movimento das atividades com o gado, sobre o solo seco do Pantanal e parece se descolar de sua memória. Ele, autor-criador, não poupa esforços na tarefa de transformar sua história ou o conto numa narrativa capaz de recolocar no centro das atenções do leitor a faina colonizadora, transmitindo à região pantaneira o lugar que passaria a ocupar no contexto social, político e econômico, primeiramente mato-grossense e depois sul-mato-grossense. A poeira traz a 
trama narrada, assentando ainda os esteios de sustentabilidade na memória familiar, não raramente confundida com a história do local. As partículas integrantes da poeira são fragmentos de histórias de vidas às quais o autor recorre com a liberdade criativa de conferir ao conto um misto de verossimilhança e de realismo, o que será reafirmado no filme $A$ Poeira.

É possível que Proença, ao conceber sua história, estivesse cumprindo um dos desejos de José de Barros, autor de Lembranças. Falecido o autor em 1950, o texto de Barros só veio a ser publicado muitos anos depois. O opúsculo referido se tornou a fonte mais borbulhante para a produção memorialista subsequente, cumprindo a expectativa do autor que, com extrema sagacidade e clareza de seu lugar social, escrevera:

Principiei hoje a escrever minhas lembranças, mesmo na incerteza de serem compreendidas por meus filhos, aos quais exclusivamente escrevo.

Ninguem mais me faria dar ao trabalho de colecionar fatos ocorridos em minha existência.

Espero que meus filhos terão o cuidado de ler e guardar estas memórias, como eu conservo, qual um tesouro as cartas que meu pai me dirigiu. (BARROS, 1987, p. 9).

Lembranças favoreceu em grande medida os autores que, desde a segunda metade do século XX, tomaram o Pantanal ambiente privilegiado para seus escritos. O Pantanal da Nhecolândia se transformaria no espaço mais fértil para a elaboração de obras de características laudatórias à região ou aos pioneiros, quando não a ambos. Potencializava-se a invenção de uma história - repita-se a título de clareza deste nosso texto - baseada na memória dos herdeiros, genéticos ou por associação, dos homens que após o fim do conflito com Paraguai, em 1870, se fixaram no Pantanal hoje localizado no estado de Mato Grosso do Sul.

A noção de invenção aqui empregada encontra-se adequadamente explicada por Albuquerque Júnior, pautada no entendimento de que o historiador conta uma história, narra; apenas não inventando os dados de suas histórias (ALBUQUERQUE JÚNIOR, 2007, p. 63), mas realiza/opera uma reconfiguração do passado a partir das questões contemporâneas. O passado é um fenômeno passível de releituras na medida em que o presente o toma como uma fonte fornecedora de indícios e perspectivas de respostas para dilemas e angústias manifestadas no seu "pós-morte". O passado alcança relevância no presente que o invoca e clama por seu comparecimento. A identidade procurada no presente parece carecer de sustentáculos alocados no passado e, na literatura, o passado adquire outro espectro, menos "responsável" e mais especulativo, talvez por isso mesmo mais livre das impossibilidades. O trabalho criativo em Poeira, por sua vez, articula a memória e a história 
para instituir o conto no qual as experiências no passado são atualizadas pela pena do autor e pela articulação com as várias possibilidades de recepção, pelo leitor comum, do conteúdo ali grafado.

O trançado resultante da ligação história e literatura é resistente, embora se possa recorrer a assertiva seguinte, na expectativa de encontrar as nuanças dos tentos que lhe sustentam a forma e a resistência:

\begin{abstract}
O conhecimento histórico torna-se, assim, a invenção de uma cultura particular, num determinado momento, que, embora se mantenha colado aos monumentos deixados pelo passado, à sua textualidade e à sua visibilidade, tem de lançar mão da imaginação para imprimir um novo significado a estes fragmentos. A interpretação em História é a imaginação de uma intriga, de um enredo para os fragmentos de passado que se têm na mão. Esta intriga para ser narrada requer o uso de recursos literários como as metáforas, as alegorias, os diálogos, etc. Embora a narrativa histórica não possa ter jamais a liberdade de criação de uma narrativa ficcional, ela nunca poderá se distanciar do fato de que é narrativa e, portanto, guarda uma relação de proximidade com o fazer artístico, quando recorta seus objetos e constrói, em torno deles, uma intriga. (ALBUQUERQUE JÚNIOR, 2007, p. 63).
\end{abstract}

Em Poeira, encontramos fragmentos de uma história local, tomada pelo autor que a transforma em paradigma da história pantaneira, enxertando-a de atos "heroicos" decorrentes da extenuante forma de vida nas fazendas pantaneiras. A invenção nessas circunstâncias não se deslinda da historicidade, embora assinale com tentativas de abstrair a vida pantaneira, encerrando esse modus vivendi na trama desnovelada pelos personagens do filme. A vida na fazenda se desenrola em torno do trabalho com o gado, personagemmercadoria no processo histórico em que a relação sociedade e natureza se consolidam em variados planos do cotidiano. As personagens do conto integram a paisagem do local tanto quanto os animais bovinos. A dramaticidade vivenciada por elas só pode ser compreendida e considerada de forma complementar ao "papel" ocupado pelos animais integrantes do contexto (bovinos e equinos). Assim, o fluxo narrativo não pende para a introspecção nem dá vazão aos sentimentos das personagens.

Não seria exagero comparar a narrativa de Nessa Poeira ao piraim utilizado para conduzir a boiada: os homens, tanto quanto os bois, alinham-se aos estalos de suas argolas; o ruído como o acontecimento violento da morte não desestabiliza a personagem, mas o desperta para a rudeza do meio. Feito artesanalmente numa trama de couro seco e argolas de aço, o piraim é instrumento rudimentar que serve para conduzir os bois. Feita artesanalmente numa trama de memória, tradição e poesia, a narrativa de Proença quer-se o motor da história do pantaneiro. Ambos, narrativa e piraim, vão dizer respeito ao movimento das coisas no mundo pantaneiro, em Proença representado não em sua forma 
mais convencional de paraíso turístico, mas como um ambiente rude, com pessoas de meias palavras, no qual bichos e homens parecem se entender melhor que homens e homens. É com base nesse prisma que a historicidade de Proença se constitui.

O amalgama com a história representa o chão do processo criador de Augusto Proença, autor que imerge em fontes históricas e delas extrai informações estruturantes de suas histórias. Seus escritos decorrem de processos investigativos semelhantes aos que os historiadores empregam em sua tarefa. Um exemplo disso é o recurso ao Boletim da Nhecolândia, periódico publicado pelo Centro de Criadores da Nhecolândia (sub-região pantaneira) e publicado ao longo dos anos 1930-1940. (PROENÇA, Augusto César, 2007. Entrevista). ${ }^{6}$ Esse jornal, ao lado de Lembranças para meus filhos e descendentes, ocupa um lugar de relevo na medida em que contempla conteúdos diversos (de receitas, contos, informações sobre a pecuária a informes mais gerais), ele expressou a relevância econômica dos proprietários de fazendas do pantanal nhecolandense, indicando ainda um perfil cultural desses proprietários, ciosos em construir um veículo que articulava e difundia informações importantes aos interesses locais. No processo criativo de Proença, o Boletim e as informações familiares compuseram o conjunto de dados que emolduram certo grau de historicidade presente em seus textos, conferindo-lhes aceitabilidade como se fossem textos históricos, quando preenchem competentemente os campi da crônica histórica. Sobre suas fontes, o autor afirma:

[...] então eu procurei fazer um livro através da tradição oral; eu ouvia muito meu pai, meu avô, minha mãe. [...] eu organizei um livro com a memória pantaneira que é um livro que aborda todos os aspectos, assim, da vivência dos pioneiros através de artigos que eles escreveram num jornalzinho chamado "Boletim da Nhecolândia", na década de trinta e quarenta né! [...] Então tirei uma série de artigos e organizei esse livro com algumas crônicas minhas também, alguns depoimentos afetivos [...]. (PROENÇA, Augusto César, 2007. Entrevista).

Poderíamos invocar para este excerto da entrevista de Proença o mito de Thoth presente no Fedro de Platão. De modo resumido, ao apresentar ao rei Tamos seus inventos, Thoth afirmara que a escrita, uma de suas várias invenções, ajudaria na memória dos homens, ao passo que o rei replica, afirmando:

Essa descoberta, na verdade, provocará nas almas o esquecimento de quanto se aprende, devido à falta de exercício da memória, porque,

\footnotetext{
${ }^{6}$ Nessa entrevista, ao tratar do processo de criação, Proença ressalta a importância do Boletim enquanto manancial informativo para seus textos.
} 
confiados na escrita, recordar-se-ão de fora, graças a sinais estranhos, e não de dentro, espontaneamente, pelos seus próprios sinais. Por conseguinte, não descobriste um remédio para a memória, mas para a recordação. (PLATÃO, 1973, p. 34).

Augusto Proença faz o processo inverso ao da recordação, mesmo se valendo da escrita. É a lembrança que, uma vez em sua memória, volta por meio do verbo, plena de sentido, num movimento de dentro para fora. Os fatos do passado deixam de ser uma simples recordação para se tornarem uma experiência vivida, mesmo que por tabela, isto é, pela memória de seus antepassados. $O$ fazer literário se dá num terreno fértil desta forma de experiência. Não é o fato do acidente narrado em si, pois ele pode não ter existido nas circunstâncias explicitadas pelo texto, ou pelo contrário, muitos acidentes como este já aconteceram ao longo da história de ocupação pantaneira pelo não-indígena, mas se trata da forma como ele adquire uma importância na narrativa, pois vai transcender o fato e transmutar-se em matéria humana. Daí, a narrativa literária ter uma maior liberdade para projetar sua sombra sobre o fato histórico. Trata-se de um processo de escrita de uma narrativa assentada numa história de transmissão oral.

Como já demonstramos em outros trabalhos, ${ }^{7}$ a oralidade é um fenômeno integrante da identidade pantaneira, condição que se apresenta na ação do autor, oferecendo-lhe credibilidade e, ao mesmo tempo, sublinhando sua relação de pertença ao meio sobre o qual se debruçou na mecânica criativa do texto literário. Temos uma espécie de encontro de tradições que autorizam a escrita de Proença: o pertencimento às famílias de "pioneiros" e, na mesma proporção e intensidade, o compartilhamento da identidade pantaneira. $O$ texto e a entrevista explicitam certa autoridade reivindicada pelo autor em relação ao conteúdo do conto, uma vez que Augusto Proença é descendente dos colonizadores, condição que o favoreceu no acesso às memórias familiares. Essas memórias se atualizam, adquirem e transmitem outros significados por meio da ficção que necessariamente não é mais memória, mas que nas suas origens beneficiou-se uma espécie de memória herdada (POLLACK, 1992).

Prosseguindo na tentativa de compreender a emergência de uma representação sobre o Pantanal e na qual os trabalhos de Augusto Proença são relevantes, a elaboração de Poeira, seja no campo literário (conto), seja no cinema a partir do roteiro do próprio autor, nos coloca frente a frente com o espectro do Pantanal desbravado por pioneiros, os antepassados de Proença, mixados pelo poder sedutor e assustador da região alagadiça.

Ao responder sobre sua ligação com o Pantanal, Proença é categórico:

${ }^{7}$ Consultar, por exemplo, Fernandes (2002) e Leite e Fernandes (2003, p. 43-62). 
É tem um sentido muito grande, muito vasto porque o Pantanal sou eu; e eu sou o Pantanal! Porque eu tive muita chegança vamos dizer assim. Esse é um termo de Manoel de Barros; mas eu acho que ainda não escrevi a coisa que eu queria escrever sobre o Pantanal; ainda não saiu, tá saindo; talvez saia, talvez não saia! Eu já tô meio, também já lá mais pra lá do que pra cá; mas eu tô... eu acho que ainda preciso escrever aquilo que eu gostaria de escrever sobre o Pantanal; talvez seja no roteiro de cinema: eu tô já estou aí, esboçando um longa metragem né? Que vai ser assim baseado nesses livros que eu escrevi de ficção, história. (PROENÇA, Augusto César, 2007. Entrevista).

O Pantanal de Proença é mítico tanto quanto histórico, na medida em que ele se vê compelido a considerar que a ação humana sobre o ambiente é também deletéria. Seu trabalho consiste em fundir essa dupla dimensão a respeito de um ambiente que aos poucos foi sendo edenizado, mas sofre a ação da cultura. Por isso, é possível compreender a força do ambiente nos textos do autor, o que conduz à sensação de que o palco é mais relevante do que a trama e os personagens. Uma boa pista para essa possibilidade aparece no livro Raízes, obra em que, na avaliação do autor, a terra pantaneira tem a função de ocupar o centro da história, submetendo a ação humana à sua presença:

Raízes [...] é uma alegoria é um Pantanal uma recriação muito fantástica do Pantanal sabe? Eu queria botá personagem, "Raízes" não tem um personagem, personagem é assim digamos um tropeiro, o grande personagem de Raízes é a terra, é o Pantanal o cavaleiro entra apenas com uma... uma vamos supor um background né? Eu gostaria de botar um povo anos à frente da razão da terra né? Falar a terra e contemplar com toda uma civilização, de uma comunidade anos dizer assim e Raízes é diferente é a terra pantaneira que é a personagem principal, personagem também como uma composição na paisagem. (PROENÇA, Augusto César, 2007. Entrevista).

Mas se em Raízes o autor optou por conceder à terra pantaneira o status de personagem principal, reproduzindo o entendimento de que o homem pode ser modelado pelo espaço, pela geografia do lugar, no conto, a cultura ganha relevo e institui-se como leit motiv da história. Mesmo assim, em ambas narrativas literárias define-se um estilo de Proença, no qual as personagens, enquanto indivíduos esmaecem no contraste com o ambiente. Esta afirmativa merece uma explicação: não é o poder de ação das personagens na trama, muito menos seus traços identitários decorrentes do papel que ocupam no meio social que perde a cor na narrativa proenciana, mas opera-se o fenômeno de ocultamento da individuação, ou seja, a personagem torna-se representativa de um tipo mais ou menos comum do ambiente narrado. Se fizermos um contraponto com um Riobaldo ou Diadorim guimarosianos, ou uma Fernanda Seixas alencariana, ou ainda uma Capitu e um Bentinho ou um Brás Cubas machadianos, notaremos que são indivíduos fortes, cujas decisões afetam o desenrolar da 
trama. No caso de Raízes e de Nessa poeira..., as personagens são importantes no cenário em que atuam, sem o qual, por sua vez, seria pobre sem a presença delas. No entanto, suas ações são aquelas esperadas no organismo social, de modo que não cabe a elas provocar uma ruptura dentro da ordem cotidiana. Por isso, em Nessa poeira..., com exceção de Zé Bento, uma personagem coadjuvante, na medida em que leva o anúncio da morte do pai, nenhum outro nome próprio é dado. É possível pensar que a força das personagens esteja naquelas imagens da memória que inspiraram o autor, ou seja, o vigor estaria depositado no passado da colonização levada a cabo pelos antepassados de Proença.

As pinceladas de práticas e marcas culturais se fazem mais evidentes no conto. Isso tem a ver com a forma como o autor concebe sua escrita e seu projeto de escrita.

Cabe antecipar um pequeno sumário do que foi visto até aqui. Augusto Proença é um escritor cuja memória familiar e pantaneira, adquirida principalmente por meio da transmissão oral e do acesso a raras fontes escritas, como o Boletim da Nhecolândia, colocase como a principal ferramenta para a tessitura literária. Por isso, podemos vislumbrar o elemento histórico em sua narrativa, o qual passa a ser ainda mais acentuado pelo estilo em que as personagens são coletivizadas. Há então no ambiente um fundo humano, como se o Pantanal ganhasse vida pelas palavras do escritor. É o silêncio dos brejos, o namoro dos jacarés e sapos, o clamor das matas, cenas em que homem, animal e natureza pulsam o espetáculo da vida. Isso parece ficar evidente no seguinte trecho de Nessa Poeira:

Continuavam a varar capões, largos, cerrados e iam se perder lá longe, no silêncio dos brejos, onde a onça bebia água, o sapo namorava a sapa, e o jacaré com a jacaroa roncavam, alumiados de lua - o pai contava. (PROENÇA, 1996, p. 34).

A narrativa de feitio histórico-literário irá, também, tornar-se aberta à representação do ambiente transformado pela cultura do homem local, mesmo que transcendo-o todo momento. Tal dinâmica não corresponde ao emprego ilustrativo e muito menos exótico do ambiente, como identificado em boa parte da literatura regionalista do século XIX, mas a paisagem e a cultura local no texto identificado incumbe-se da função humanizadora no conto. Mais uma vez homem e mundo natural constituem um só corpo, sendo o espírito empreendedor/domesticador do homem na lida do campo o elemento diferenciador entre eles. Não é demasiado observar, a natureza proenciana não é aquela aprazível, encontrada nos folderes de agência de turismo. Ela é rude e embrutece o homem que nela trabalha. Mas também é na relação com o mundo natural que o homem se humaniza, porque da natureza irrompe o sentido de sua existência que justifica sua historicidade. Ou como diria um afamado poeta pantaneiro: "Eu queria ser lido pelas pedras" (BARROS, 1997, p. 69) 
Até aqui, nosso foco recaiu sobre o fazer literário de Proença e de sua relação com a história por meio da atualização da memória local. Cabe destacar que, ao ser transposto da linguagem literária para a cinematográfica, Nessa poeira... reintitulado A Poeira: uma história do Pantanal ainda ressalta os modos de ser e fazer dos pantaneiros ${ }^{8}$.

De circulação restrita e com ares de produção caseira, o filme repõe a narrativa do conto sob a linguagem cinematográfica, destacando elementos do cotidiano pantaneiro. É destacável a capacidade interpretativa do menino que, à espera do pai-peão, invoca outros personagens da linguagem artística do ambiente rural brasileiro, como o menino-daporteira. Outro aspecto significativo no filme refere-se à apropriação do imaginário pantaneiro, o que confere à narrativa fílmica uma ligação com o universo mítico local, sempre habitado por seres fantásticos que se mesclam ao cotidiano do homem pantaneiro.

A imagem materna e a expectativa do menino oferecem indicações a respeito da expectativa pelo pai, um peão de fazenda envolvido nos afazeres inerentes ao ambiente pastoril do Pantanal. O pai, a figura masculina, é a referência identitária para o menino tanto quanto o é para a ambiência local. O espaço das fazendas pantaneiras e suas atividades de maior visibilidade transformam o homem na principal personagem da trama - seja a artística, seja a histórica - colocando maior peso na ação levada adiante pelo homem-peãopai. Quanto à mãe, a imagem possibilita sua presença no ambiente historicamente identificado como de domínio feminino: a cozinha. No filme, lá a encontramos resignada, cultivando a melancolia originária da ausência do esposo morto; a entrada do filho, infante ingênuo que anuncia o retorno da imagem do pai, em meio a uma densa nuvem de poeira interrompe a dureza da ação e do lugar da mãe-sofredora-companheira, instigando-a certo instante de dúvida sobre a volta de seu homem. Ao mesmo tempo, sua força se apresenta no exercício de dominar o lugar e o "papel" de mãe e de mulher num ambiente cultural em que as relações de poder se estendem às relações de gênero sem maiores escrúpulos.

A poeira, resultado do movimento provocado pelo vento sobre o solo seco é mais que a agitação das partículas de terra; é uma imagem no interior da qual se apresenta a memória do menino à espera de quem a pouco lhe ensinava as coisas da vida no lugar. A nuvem de poeira que antes envolvia o retorno do pai, agora alimentava a imaginação do garoto, confundindo sua mente que insistia em desejar o retorno de alguém desaparecido, mas que talvez se fizesse novamente presente. É sintomático que a poeira indica a representação mais forte da ausência, mas também se presta a oferecer suporte para a dúvida, transformando-se num recinto de expectativa e substituindo a figura que dela emergiria, ou seja, o pai que chegava da lida. Mas a poeira traz também uma referência lapidar ao lugar, o Pantanal, um espaço marcado pela dualidade das enchentes revitalizadoras e das secas

\footnotetext{
${ }^{8}$ A Poeira: uma história do Pantanal. DVD. Duração $14 \mathrm{~min}$. Sistema NTSC. Formato XDCAM HIGHT DEF. 16:9. Roteiro e direção geral: Augusto Cesar Proença. Produção e dir. associada: Hélio Godoy. 2008. 0 filme foi concebido originalmente para o público infanto-juvenil.
} 
ameaçadoras; ela integra o cenário na mesma proporção em que as noções e representações paradisíacas adjetivam o Pantanal. ${ }^{9}$

Para o menino, a poeira é um indício positivo como também é o fenômeno que envolve a imagem do pai; a mãe por sua vez não sente, tampouco considera aquele evento como um instante digno de boas referências ou da presença do marido. A poeira, segundo sua compreensão, é marca do ausente e não traz aquele outro que desapareceu. A frase que intitula o conto é a síntese da dor pela ausência, pela negação da positividade enunciada pela areia, ao ser convocada pelo filho para receber o pai, a resposta é dolorida e saudosa: “- Nessa poeira não vem mais seu pai!"

É importante, ainda, observar que a linguagem fílmica é distinta daquela verificada no conto, considerando-se ainda o aspecto que norteia o filme enquanto uma produção destinada a um público infanto-juvenil. Contudo, nos parece significativo apontar que mesmo se tratando de estruturas discursivas - e artísticas - distintas, elaboradas com finalidades também diferenciadas, A poeira: uma história do Pantanal se difere, na profundidade reflexiva, de Nessa poeira não vem mais seu pai. No conto, a representação da cultura pantaneira faz fundo para o significado humanizador da narrativa. No filme, a representação da cultura pantaneira limita-se a uma referência ao ambiente pantaneiro, isto é, ocorre uma primazia do significante sobre o significado, de modo que o vestuário, a fazenda escolhida para a filmagem, o fogão à lenha em que cozinha a mãe, a fotografia do filme que privilegia animais típicos da região e as personagens com traços étnicos de locais ${ }^{10}$ são referentes esvaziados do lirismo encontrado na narrativa escrita.

Conto e filme se debruçam sobre a mesma experiência, mas é no conto que se localiza plasmado certo grau de apropriação estética da experiência histórica do homem pantaneiro na sua labuta constante com o mundo que o cerca e do qual é também um componente. Por isso, voltamos ao conto e à obra de Proença.

Pode-se afirmar com segurança que a experiência narrativa encerrada nas duas obras o conto e o filme - tem profundas ligações com a experiência de uma cultura oral, marca de uma forma existencial secular sobre um ambiente peculiar e ambíguo. Em outro momento e sondando outros aspectos da narrativa no Pantanal, anotamos que

\footnotetext{
${ }^{9}$ Nos anos de 1995 e 1996, período em que realizávamos entrevistas para outras pesquisas no e sobre o Pantanal sul-mato-grossense, empregando a metodologia da história oral, tivemos a oportunidade de gravar diversas narrativas, nas quais a questão das enchentes e das secas foram objetos de observações importantes. Em uma das mais expressivas entrevistas, realizada com um antigo condutor de boiadas, encontramos a seguinte descrição de um encontro singular: "Não adianta falá, porque [se] eu tenho que encontrá com enchente, vô encontrá logo! [...] então eu saí do poso; daí uma meia légua encontrei com a enchente. Ela veio cumo animar que vem pegano terra assim. Então aquela água vai levantando aquela poera e a passarada vinha acumpanhano!". (Grifos nossos). (MEDEIROS, Raul, 1995. Entrevista).

10 É importante observar que o pai do menino é representado por um ator que é peão na fazenda em que foram realizadas as locações.
} 
[...] o Pantanal é uma espécie de repositório de tradições. Estas integram o universo local e contribuem nas formas de viver no local, além de relacionarem-se com a própria identidade do pantaneiro. Nesse prisma, a tentativa de compreender a cultura pantaneira passa pelas formas desenvolvidas pelo homem no Pantanal para integrar a natureza ao seu cotidiano. Parece-nos, portanto, que a relevância adquirida pela tradição desempenha um papel importante nas formas de viver no Pantanal e integram a história do homem e da natureza nessa região. (LEITE; FERNANDES, 2003, p. 63).

Apesar de Proença se preocupar com investigações a respeito do passado regional, uma forma de reafirmar quase sempre a primazia dos pioneiros, seus antepassados no "desbravamento" e fundação de fazendas, a oralidade enquanto componente cultural da região é central no desenvolvimento da trama. É no âmbito do "falar" ou do "contar" que a memória local se reedifica, transferindo um patrimônio intelectual decorrente da experiência humana no universo do trabalho e das sociabilidades possíveis nas fazendas, nas margens dos rios e baias, nas viagens com o gado, entre muitos outros momentos no interior do Pantanal.

É pungente a memória oral na obra de Proença. Primeiramente, porque o autor se constitui em um dos nós da teia da tradição oral, no sentido benjaminiano. Ou seja, vindo de uma família "desbravadora", o autor de Nessa poeira... atualiza um passado pantaneiro filtrado pela voz de seus pais, pelas histórias que ouvia na infância, enfim, pela própria tradição oral que o circundava. Num segundo momento, cabe observarmos que a oralidade vai se desdobrar num estilo literário em sua obra.

A presença da oralidade é bastante comum na literatura latino americana e também podemos observar suas marcas em estilo muito variado. Carlos Pacheco, ao estudar três autores representativos da América do Sul: Guimarães Rosa, Juan Rulfo e Augusto Roa Bastos, observa que:

Durante todo el proceso histórico latinoamericano, muchos de los textos que hoy consideramos parte fundamental de la literatura latinoamericana se han nutrido de lo que podría llamarse - en sentido muy amplio - "cultura popular". Esta es em sí misma una amplia línea de investigación, donde vários enfoques son posibles. Uno de ellos, por ejemplo, consiste em el estúdio de esse nutrido sistema de textos denominado "literatura testimonial", cuya autoria se debe por lo común a escritores profesionales o a científicos sociales, pero basándose siempre sobre los recuentos de informantes calificados ya menudo intentando preservar en la obra resultante la estructura narrativa y el estilo peculiar de su fuente oral popular.(PACHECO, 1992, p. 19). 
Augusto Proença filia-se à tradição literária testemunhal, em decorrência de sua trajetória de vida, mas também promove um estilo peculiar de lidar com a oralidade, um estilo cuja escrita se dobra ao ritmo da fala e suas pinceladas desenham o contexto de enunciação das histórias. Há marcas linguísticas da fala local, no entanto, elas não são o elemento mais importe da oralidade em sua obra. Seu estilo promove algo muito mais abrangente que o simples registro da fala. Ganha destaque em sua narrativa uma cultura oral. São perceptíveis tanto em Raízes como no conto em questão o modo como a cultura oral entranha-se na vida social dos pantaneiros, como o universo de histórias é importante para a formação dos sujeitos, os momentos e situações em que são contadas narrativas que habitam a denominada "cultura popular pantaneira", o impacto destas histórias no modo de ser de cada sujeito local, a celebração e a alegria do canto. Enfim, a oralidade para Augusto Proença é um sistema de comunicação pelo qual as pessoas sonham e vivem, constituem um modo de ser e, consequentemente, uma identidade.

Nesse sentido, o autor desbobra a tradição latino americana, criando um estilo próprio, nem tanto experimentalista, como em Rosa, nem tão preocupado em ser fiel à linguística local, como em Rulfo, nem tanto transformando a oralidade numa bandeira dos sem voz na história, como em Roa Bastos. Podemos afirmar que a grande genialidade no emprego da oralidade em Proença reside exatamente em não ter como fim tais características dos autores citados, mas que elas, mutatis mutandis, não deixam de se fazer presentes em seu texto.

Cabe aqui uma citação, mesmo que um pouco estendida, do conto em que a maneira de lidar com a tradição oral se faz presente:

Nas noites de verão, quando os vaga-lumes tatuavam a sombra escura do tamarineiro e um vento-norte-suave-soprava, pai e filho se sentavam debaixo da velha árvore, tomando a fresca. Então o pai contava estórias de bichos e de assombrações que vagueavam pelo Pantanal. Da anta amiga, que saía do mato e assobiava no largo, chamando a gurizada; do bezerrinho, nascido com duas cabeças e seis patas; da vaca malhada, que cagava na panela e fazia beeé... beeé... que nem um bezerro fazia, sentido-se perdido da mãe num recanto solitário de curral. E contava do fogo dos enterros alteando um clarão fumoso no meio da noite; das almas penadas dos afogados, que perpassavam a noite dos corixos perseguindo canoa de pescador; da manceba do padre, que virava mula-sem-cabeça e com seu casco fino coiceava criança levada; do cipó voador, que carregava os velhos e os meninos, depois de mortos, lá para junto das estrelas. E acabava cantando cantigas para o filho dormir.

Vai papão, vai embora

de cima do telhado,

deixa dormir o menino

um soninho sossegado. (PROENÇA, 1996, p. 35). 
A maneira inventariada com que enuncia as histórias de circulação oral no Pantanal deixa entrever o diálogo com viajantes e memorialistas da região, principalmente a do português Joaquim Ferreira Moutinho (1833 - 18??), autor de Notícia sobre a província de Mato Grosso, seguida de um roteiro de viagem da sua capital a S. Paulo." Só que, ao contrário de Moutinho, que fazia questão de se colocar como portador de uma "cultura superior" em relação aos "atrasados", o que o tornava refratário a algumas lendas circuladas na região, Proença faz um inventário de diferentes histórias situando-as dentro de um contexto de enunciação: no caso, a performance e a afetividade paterna que a cerca fazem-se presentes. Além disso, há um ritmo de enunciação na forma com que estas histórias são apresentadas, lembrando o ritmo próprio da voz quando em performance. Atentemos para as onomatopeias entremeando o texto e para o acalento ao final da descrição. $O$ destaque dado ao ritmo na narrativa escrita cria um narrador familiarizado à cultura oral, sensível ao mundo afetivo e cultural mediado pela voz.

Há ainda na contemporaneidade um ambiente propício à oralidade, conforme pode-se perceber em vários trabalhos realizados sobre essa questão e que encontraram no Pantanal o ambiente que ofereceu a problemática para pesquisa. Essa situação é antes tudo o reconhecimento a respeito do sentido e do lugar da oralidade na cultura pantaneira recente. Se no filme $A$ poeira, a oralidade ameaça ser suplantada pelo conjunto de imagens que materializam a trama e os diálogos, ainda que tenham ligações com essa prática cultural, funcionam como amparo do jogo imagético; em Nessa Poeira, a oralidade se manifesta submetida à narrativa autoral, ferramenta discursiva que (in)forma o leitor a respeito de uma tragédia inerente às formas de vida do lugar. Mas o conjunto de situações que constituem o conto é revelador da presença da oralidade enquanto estrutura formadora da identidade e do conhecimento empírico das personagens.

Ao procedermos a maiores avanços sobre a produção intelectual de Augusto César Proença logramos contemplar os procedimentos criativos de seus trabalhos, além de perceber seu diálogo com a memória local. A trajetória desse autor está acentuada por sua relação com o Pantanal e em consequência dos laços familiares, fenômeno que ganhou uma importância indiscutível na produção literária iniciada nos anos 1970, momento em que ele se encontrava distante daquele ambiente que se transformou no mote de sua escrita.

No corpus analisado (especialmente textos literários e entrevistas), as referências ao Pantanal aparecem de forma intensa a partir do livro Raízes do Pantanal, publicado em 1989. Embora Raízes não possa ser considerada a obra primeira de Proença, é no seu interior que encontramos a personagem mais expressiva que se fará presente em toda a literatura que aparecerá depois: o Pantanal. Ainda que Raízes apresente o Pantanal como sua principal personagem, de acordo com o próprio Augusto Proença, o livro foi escrito no Rio de Janeiro, numa fazenda em Cabo Frio, na qual o autor cultivava bananas. Nesse sentido, a construção

${ }^{11}$ Uma análise sobre a oralidade nesta obra de Moutinho pode ser encontrada em Fernandes (2007). 
do Pantanal de Raízes recorre à memória coletiva, nesse caso, essencialmente a memória familiar do autor, encaminhando para a elaboração de uma representação escrita que articula a rusticidade do ambiente e seus supostos efeitos sobre as decisões e as ações das personagens. O primeiro livro escrito por Proença foi Snack Bar, um conjunto de contos publicado em 1979, que nada diz sobre o Pantanal, constituindo-se como um livro cujo conteúdo comporta conflitos humanos ambientados no espaço urbano. (PROENÇA, Augusto César, 2007. Entrevista). O urbano só retorna às preocupações do Autor em 2003, em obra fragmentada, um livro de crônicas a respeito da Cidade de Corumbá cujo título é "Corumbá de todas as graças". Certamente, esse retorno ao mundo urbano resulta num texto mais simples e frágil quando pensado em relação a outros escritos.

Ao decidir narrar o Pantanal, Proença procura cercá-lo, utilizando-se de vários artifícios, inclusive o literário e o cinematográfico. A narrativa ou as duas narrativas aqui tocadas se sustentam no ato inventivo ou representacional empregado na constituição da história. Ambos, conto e filme, integram-se ao conjunto de representações sobre o Pantanal e, como Proença afirma em sua entrevista de 2007, numa representação "verossímil e legítima" do meio que buscam representar.

O Pantanal inventado por Augusto Proença tem claramente a intenção de ser fiel ao "real enxergado" e vivido por esse autor. Há que se pensar, em outro momento, a força da tradição, um fenômeno imponente na escritura proenciana e que pode ser uma chavemestra para melhor compreender os sentidos que a maior parte de sua produção trata de consagrar. É possível arriscar afirmando que livros como Pantanal; gente, tradição e história postulem uma ação normativa sobre o passado, buscando ainda consagrar a permanência da imagem do pioneirismo como ação criadora do Pantanal nhecolandense. A relevância do passado encontra sentido na literatura de Proença quando seu conteúdo é transformado em trama que preserva a verossimilhança, deslindando-se pari passu da singularidade responsável pela historicidade ou pelos eventos tomados como reais. O passado tomado e reelaborado guarda referências aos pioneiros porque a obra desses seus antepassados oferece excelente material literário, possibilitando ainda o fortalecimento da memória daqueles que implantaram um modelo pastoril vitorioso na região da Nhecolândia. Em Raízes do Pantanal, a personagem nuclear é o Pantanal, segundo o próprio Proença, mas o homem que perambula sobre o lugar é uma personagem-síntese daqueles colonizadores que se instalaram na região entre os anos 1870-1900; reivindicando a terra como herança ao mesmo tempo, esses atores, a saber, Joaquim Eugênio Gomes da Silva (Nheco) e José de Barros induziram o processo de conquista e formatação da região, hoje denominada Nhecolândia.

A partir dos textos aqui lembrados, conseguimos apontar que o trabalho de fortalecer a memória é parte da "ação pedagógica" que reivindica o poder das famílias tomadas como pioneiras no "desbravamento" do Pantanal. O passado é adotado como mecanismo que 
garante e legitima o presente na medida em que preserva no seu núcleo um conjunto de eventos que, ao serem evocados, repercutem interesses políticos e econômicos, mas, sobretudo simbólicos.

A escritura de Augusto César Proença retoma o local e o regional no contexto da calcificação de uma representação do Pantanal sul-mato-grossense, num período - os anos 1970 - em que a região era progressivamente instituída como paraíso das espécies. Se o Pantanal de Proença é maior que algumas de suas personagens, a história que emana da ficção do autor contempla a ação dos colonizadores - rústicos ou não - os quais cumpriram a labuta derreante, subordinaram em grande medida a natureza do lugar, transformando-se nos senhores da memória a ser referida como fenômeno explicativo da origem da região. Em se tratando de um instante em que ocorrem profundas alterações no que se refere às fazendas locais, especialmente pela presença de proprietários outsiders, o significado simbólico e a memória do colonizador se fortalece nos escritos que tomam o passado como razão narrativa.

\section{Referência}

ALBUQUERQUE JÚNIOR, Durval Muniz de. História: a arte de inventar o passado: ensaios de teoria de história. Bauru: Edusc, 2007.

BARROS, José de. Lembranças para meus filhos e descendentes. São Paulo: Centro Gráfico, 1987.

BARROS, Manoel de. Livro sobre nada. 4. ed. Rio de Janeiro: Record, 1997.

BARTHES, Roland. O rumor da língua. Lisboa: Ed. 70, 1988.

BENJAMIN, Walter. O narrador: In: _ _ _ _ _. Magia e técnica, arte e política: ensaios sobre literatura e história da cultura. 7. ed. São Paulo: Brasiliense, 1996. p. 197-221.

PROENÇA, Augusto César. Prod. Eudes Fernando Leite. Corumbá. [UFGD]. Fita Cassete. 2007. $50 \mathrm{~min}$ (aprox.) Son. Entrevista.

MEDEIROS, Raul. Produção: Eudes Fernando Leite e Frederico Augusto G. Fernandes. Corumbá: Ceuc/UFMS, 1995. Filme-video, 300 min (aprox.), color., son., VHSc. Entrevista.

AQUINO, Valdomiro Lemos de (filme-vídeo). Produção: Eudes Fernando Leite e Frederico Augusto G. Fernandes. Corumbá: Ceuc/UFMS, 1996. 180 min (aprox.), color., son., VHSc. Entrevista. 
FERNANDES, Frederico. A voz e o sentido. São Paulo: EDUNESP, 2007.

_. _ _ . Entre histórias e tererés: o ouvir da literatura pantaneira. São Paulo: EDUNESP, 2002.

LEITE, Eudes Fernando. Um homem chamado pantaneiro. In: GALINDO, Dolores; SOUZA, Leonardo Lemos de (Org.). Gênero e tecnologias, tecnologias do gênero; estudos, pesquisas e poéticas interdisciplinares. Cuiabá: EDUFMT, 2012. p. 33-46.

LEITE, Eudes Fernando. Marchas na história: comitivas e peões-boiadeiros no Pantanal. Campo Grande: EDUFMS, 2003.

LEITE, Eudes Fernando; FERNANDES, Frederico Augusto Garcia. Oralidade no Pantanal: vozes e saberes na pesquisa de campo. In: FERNANDES, Frederico Augusto Garcia (Org.). Oralidade e literatura: manifestações e abordagens no Brasil. Londrina: Eduel, 2003. p. 43-64.

MOUTINHO, Jouaquim Ferreira. Notícia sobre a província de Matto Grosso. São Paulo: Tipografia de Henrique Schoroeder, 1869.

PACHECO, Carlo. La comarca oral. Caracas: La Casa de Bello, 1992.

PLATÃO. Fedro. Lisboa: Verbo, 1973.

POLLACK, Michael. Memória e identidade social. Estudos históricos, Rio de Janeiro, v. 5, n. 10, p. 200-212, 1992.

PROENÇA, Augusto César. Corumbá de todas as graças. Campo Grande: Gráfica Ruy Barbosa, 2003.

_ _ _ _ _. Nessa poeira não vem mais seu pai. MS Cultura, Campo Grande, ano 3, n. 1, 1996.

_ _ _ _ _ . Pantanal: gente, tradição e história. Campo Grande: Edição do Autor, 1992.

_. _ _ _. Raízes do Pantanal (Cangas e Canzis). Belo Horizonte/Rio de Janeiro: INL/Itatiaia, 1989.

SCHWARCZ, Lilia Moritz. O espetáculo das raças: cientistas, instituições e questão racial no Brasil: 1870-1930. São Paulo: Cia das Letras, 1995. 